\title{
Stress Tolerance and Symbiotic and Phylogenic Features of Root Nodule Bacteria Associated with Medicago Species in Different Bioclimatic Regions of Tunisia
}

\author{
SAlEm DJeDidi ${ }^{1,4}$, TADASHi YokOYAma ${ }^{2 *}$, NAOKO OHKAMA-OHTSU ${ }^{3}$, CHANDRA PRASAD RISAL $^{1}$, \\ Chedly ABDELlY ${ }^{4}$, and Hitoshi SEKIMOTO 5 \\ ${ }^{1}$ United Graduate School of Agricultural Science, Tokyo University of Agriculture and Technology, 3-5-8 Saiwai-cho, \\ Fuchu, Tokyo 183-8509, Japan; ${ }^{2}$ Institute of Agriculture, Tokyo University of Agriculture and Technology, 3-5-8 \\ Saiwai-cho, Fuchu, Tokyo 183-8509, Japan; ${ }^{3}$ Women's Future Development Organization, Tokyo University of \\ Agriculture and Technology, 3-5-8 Saiwai-cho, Fuchu, Tokyo 183-8509, Japan; ${ }^{4}$ Laboratory of Plant Adaptation \\ to Abiotic Stresses (LAPSA), Biotechnology Centre of Borj Cedria, P.O. Box 901, 2050 Hammam-Lif, Tunisia; and \\ ${ }^{5}$ Faculty of Agriculture, Utsunomiya University, 350 Mine, Utsunomiya, Tochigi 321-8505, Japan
}

(Received June 16, 2010—Accepted October 11, 2010—Published online December 4, 2010)

Thirty two rhizobial isolates were obtained from different bioclimatic regions of Tunisia using as trap plants, Medicago sativa, Medicago ciliaris, Medicago polymorpha and Medicago minima. To study their diversity and characterize them in relation to Mediterranean conditions, abiotic stress resistance, symbiotic properties and genetic diversity in terms of $16 \mathrm{~S}$ rRNA and nodA sequences were assessed. Five isolates from $M$. sativa, three from $M$. ciliaris and three from $M$. minima could grow at $45^{\circ} \mathrm{C}$. Only two isolates from $M$. sativa grew at $4 \% \mathrm{NaCl}$. The most stress tolerant isolates were obtained from arid soils. A phylogenetic analysis of $16 \mathrm{~S}$ rRNA genes revealed 29 isolates to be closely related to Ensifer including one (P1.3-9) that showed a 16S rRNA sequence similar to that of Ensifer meliloti and nodA sequence similar to that of Ensifer medicae. However, three isolates were categorized into Agrobacterium containing the nodA of Ensifer. Furthermore, these isolates developed nodules on original hosts. The results for the four isolates suggest horizontal gene transfer between the species.

Key words: Ensifer, stress tolerance, Tunisia, phylogeny, symbiotic properties

Legumes are frequently distributed in arid and semi-arid regions. They are pioneer plants, which can provide their own nitrogen in symbiosis with root nodule bacteria (rhizobia). In Tunisia, Medicago species as leguminous plants are naturally distributed and widely represented in the native flora (30). Many species of this genus have wide-ranging agricultural and environmental applications (15). Moreover, the annual species, collectively known as "medics", are of great importance in pastures in the Mediterranean and known to establish a nitrogen-fixing symbiosis with soil bacteria of the genus Ensifer (formerly Sinorhizobium). In the last decade, wild legumes and their symbionts have attracted the attention of ecologists due to their tolerance of extreme environmental conditions including salinity, severe drought and elevated temperatures (23).

Several reports have described stress tolerant rhizobial strains. Payakapong et al. (25) isolated a highly salt tolerant Ensifer species (Ensifer sp.BL3), and Hung et al. (14) described strains of Rhizobium, Bradyrhizobium and Agrobacterium that could grow in a medium containing $4.5 \%$ $\mathrm{NaCl}$ and also grew well at $45^{\circ} \mathrm{C}$. The diversity of rhizobia nodulating Medicago species has been widely reported (3, $4,10,38)$ including in Tunisia $(1,16,44-46)$. Three different species, Ensifer meliloti (17), Ensifer medicae (27) and Rhizobium mongolense (37), were reported as microbial

\footnotetext{
* Corresponding author. E-mail: tadashiy@cc.tuat.ac.jp;

Tel: +81-42-367-5878; Fax: +81-42-367-5878.
}

symbionts of Medicago species. In Tunisia, the genetic diversity of natural populations of rhizobia nodulating $M$. sativa, M. scutelleta, M. truncatula and M. ciliaris, was assessed by a polyphasic approach based on plasmid profiles, multilocus enzyme electrophoresis and a restriction fragment analysis of PCR-amplified DNA fragments (PCR-RFLP) of $16 \mathrm{~S}$ rRNA, the inter genic spacer (IGS) and the nitrogenfixing gene nifDK (16). Zribi et al. (45) characterized 299 isolates of rhizobia associated with Medicago truncatula in 10 Tunisian soil samples by PCR-RFLP of $16 \mathrm{~S}$ rRNA genes. These reports indicated that $E$. meliloti is a predominant Ensifer species in Tunisia and has wide genetic diversity in Tunisian soils.

Recently, many Agrobacterium strains have been isolated from root nodules of legume plants and though most were non-symbiotic belonging to Agrobacterium tumefaciens, some may represent novel biovars (19). Moreover, Velazquez et al. (39) reported for the first time the occurrence of two strains (163C and ATCC $11325^{\mathrm{T}}$ ) belonging to $R$. rhizogenes able to nodulate Phaseolus vulgaris. These strains displayed symbiotic plasmids carrying nod and nif genes phylogenetically related to those of E. meliloti. In addition, Cumming et al. (7) characterized a bacterial strain, IRBG 74, isolated from root nodules of Sesbania cannabina with a $16 \mathrm{~S}$ rRNA sequence closely related to that of A. tumefaciens. This strain contained also a symbiotic plasmid carrying nod $A$ and nifH similar to those in other Sesbania symbionts and effectively nodulated Sesbania cannabina and even some 
other Sesbania species. On the other hand, horizontal gene transfer in bacteria is widely recognized as the mechanism responsible for the widespread distribution of antibiotic resistance genes, gene clusters encoding biodegradative pathways, and pathogenicity determinants. This mechanism is also responsible for speciation and sub-speciation in bacteria (6). In the case of rhizobia, Minamisawa et al. (22) suggested the potential horizontal transfer of nod genes among bradyrhizobia and other bacterial populations in soil environments. Similarly, Bailly et al. (2) suggested that during the evolution of Medicago symbionts, horizontal transfer of nod genes might have occurred either to the common ancestor of the two Ensifer species or to one Ensifer species followed by the other. Additionally, Suominen et al. (34), when describing the structure of the common nodulation genes of Rhizobium galegae, reported that lateral nod gene transfer might have occurred from fast growing rhizobia to agrobacteria.

Tunisia is facing increasingly serious environmental problems in arid and semi-arid regions. Salinity and drought in addition to soil degradation and desertification are severe limitations for agriculture. Furthermore, these abiotic constraints may have a detrimental effect on microbiological activity leading to a reduction in crop productivity. One way to overcome these serious environmental problems is to use native Tunisian species for revegetation in arid and semi-arid regions because the genus Medicago is distributed in all bioclimatic regions of the country including arid and semiarid areas. To spread the genus Medicago into these parts of Tunisia, it is important to apply rhizobial inoculants that interact efficiently with Medicago species and are adapted to drought and salinity.

In this study, to characterize the root nodule bacteria associated with three wild Medicago species, Medicago ciliaris, Medicago polymorpha and Medicago minima, and a commonly cultivated species, Medicago sativa, in Tunisia, a polyphasic approach was used. The phenotypic characterization of these strains was conducted to evaluate their capacity to grow under abiotic stress such as severe temperatures, salinity, drought and high $\mathrm{pH}$. Their genetic properties were determined by an analysis of 16S rRNA and nodA sequences. Finally, the symbiotic properties of these representative strains were evaluated in terms of nodule numbers and acetylene-reducing activity and plant growth-promoting rates.

\section{Materials and Methods}

Isolation of Rhizobium from Tunisian soils using Medicago species as trap hosts

Five representative soil samples corresponding to different bioclimatic regions of Tunisia were used (Fig. 1). Four Medicago species; M. sativa cv. Gabes, M. ciliaris line TNC 1.8, M. polymorpha $\mathrm{cv}$. Mauguio and M. minima (natural population), were used as trap hosts. Seeds from these species were surface-sterilized with $96 \% \mathrm{H}_{2} \mathrm{SO}_{4}$ to promote germination, incubated on $0.9 \%$ agar medium at $4{ }^{\circ} \mathrm{C}$ for $24 \mathrm{~h}$, and then kept at $25^{\circ} \mathrm{C}$ in the dark for germination. Germinated seeds were placed in a $300-\mathrm{mL}$ glass bottle filled with sterilized vermiculite. Inoculation was performed using $1 \mathrm{~g}$ of soil sample dissolved in $5 \mathrm{~mL}$ of sterilized water per bottle. A sterilized $\mathrm{N}$-free nutrients solution (5) was added to each pot corresponding to a $60 \%$ moisture level which was maintained

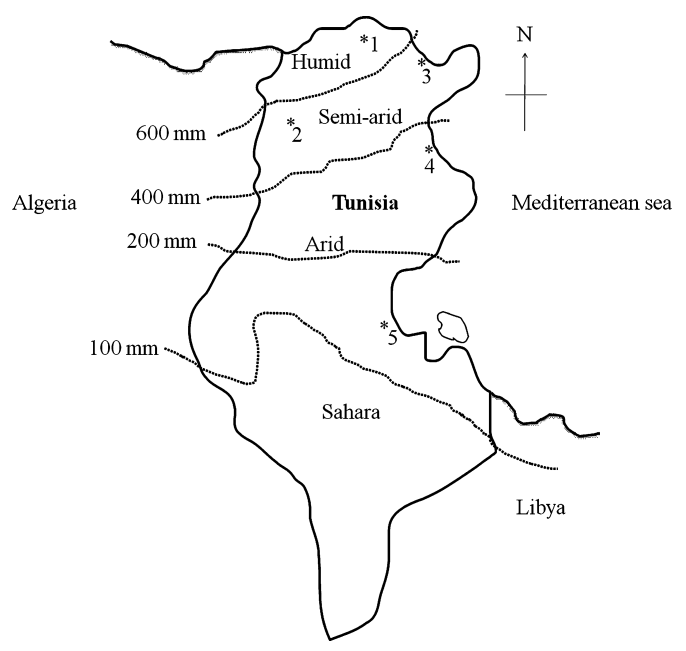

Fig. 1. Geographical locations of soils used for rhizobial isolation. 1, Mateur (texture: silty, annual rainfall: $600-800 \mathrm{~mm}$, sub-humid); 2 , El Kef (texture: silty, annual rainfall: $400-500 \mathrm{~mm}$, superior semi-arid); 3, Soliman (texture: fine silt, annual rainfall: $500-700 \mathrm{~mm}$, superior semi-arid); 4, Enfidha (texture: silt sandy, annual rainfall: $300-400 \mathrm{~mm}$, inferior semi-arid); 5, Gabes (texture: sandy, annual rainfall: 180-220 $\mathrm{mm}$, arid).

during the growing period. Plants were placed in a growth chamber under controlled conditions: A 16 -h photoperiod at $25^{\circ} \mathrm{C}$ and $8 \mathrm{~h}$ of darkness at $18^{\circ} \mathrm{C}(16,46)$. Root nodules were collected from roots of 60-day-old plants. Bacteria were isolated from these nodules according to Vincent (40). The root nodules were surface sterilized with $70 \%$ ethanol $(\mathrm{v} / \mathrm{v})$ for $30 \mathrm{~s}$ and $3 \%$ sodium hypochlorite for about 3 min and crushed in a $15 \%$ glycerol solution. A loopful of the root nodule solution was transferred to a yeast mannitol agar (YMA) medium. Single colonies were picked out and repeatedly streaked to check their purity and then pure colonies were maintained in YMA on slants at $4{ }^{\circ} \mathrm{C}$.

\section{Stress tolerance screening}

The isolates obtained from the Medicago species used in this study were examined for growth under conditions of high temperature, high salinity, alkaline $\mathrm{pH}$ and extreme drought. In the case of temperature tolerance, isolates were kept at $28^{\circ} \mathrm{C}$ (as a control), 37 , 40 , or $45^{\circ} \mathrm{C}$ on YMA plates for 4 to 5 days. The $\mathrm{pH}$ of the medium was adjusted with $0.5 \mathrm{M} \mathrm{HCl}$ or $0.5 \mathrm{M} \mathrm{NaOH}$ to 6.9 (as a control), 8,9 , or 10.5 . This test was performed on YMA plates kept at $28^{\circ} \mathrm{C}$ for 4-5 days. To check the ability of isolates to grow under different concentrations of $\mathrm{NaCl}$, the medium was supplemented with 0 (control), 1, 2, 3, or $4 \% \mathrm{NaCl}$ then incubated at $28^{\circ} \mathrm{C}$ for 4 to 5 days in YMA plates. To test drought resistance, different concentrations of polyethylene glycol (PEG 6000) were applied to the medium at a final concentration of 0 (as a control treatment), 15 , or $25 \%$. In these experiments, isolates were first grown in YM broth for 4 days at $28^{\circ} \mathrm{C}$ and then transferred to YMA plates as previously indicated. The screening for stress tolerance was performed in Petri dishes divided into equal squares as shown in Fig. 2-a. Each square was spot-inoculated with $10 \mu \mathrm{L}$ of the cell suspensions at $10^{9}$ cells $\mathrm{mL}^{-1}$ grown in YM broth at an exponential phase. After incubation under different stressful conditions, the growth of isolates was estimated in comparison with that following control treatment as follows: -, no growth; +, weak growth (10-30\% in relation to the control); ++, good growth (30-80\% in relation to the control); and +++ , very good growth (similar to the control) as shown in Figs. 2-b and c. This experiment was carried out in triplicate for each isolate and repeated two or three times for confirmation. 


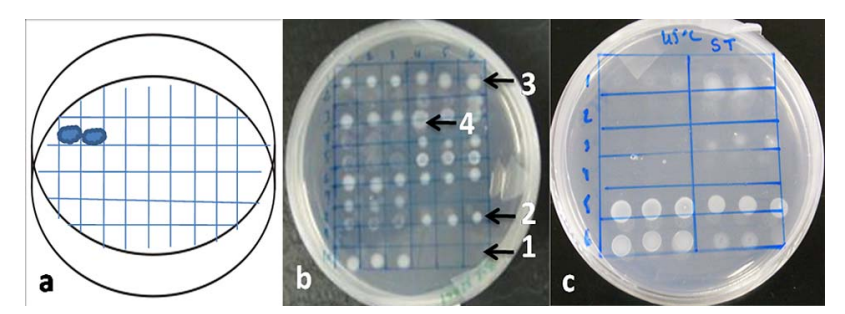

Fig. 2. Screening for stress tolerance, a: plate divided into equal squares used for screening. b: growth scores were recorded as follows: 1 ; no growth:,- 2 ; weak growth: $+(10-30 \%$ in relation to the control) 3 ; good growth: $++(30-80 \%$ in relation to the control $)$ and 4 ; very good growth: +++ (similar to the control). c: example of colony morphology after 4 days of incubation under stressful condition.

\section{Isolation of genomic DNA}

Genomic DNA of each isolate was prepared as described in Yokoyama et al. (42) with modifications. A loopful of bacterial cells was inoculated into $20 \mathrm{~mL}$ of YM broth. After 4 days at $28^{\circ} \mathrm{C}$, the cells were harvested and washed twice with TNE (10 mM Tris, $0.1 \mathrm{M} \mathrm{NaCl}$, and $1 \mathrm{mM}$ EDTA, $\mathrm{pH}$ 8) solution. The pellets were suspended in $200 \mu \mathrm{L}$ of a lysozyme solution, $\mathrm{pH} 8(25 \mathrm{mM}$ Tris, $12.5 \mathrm{mM}$ EDTA, $12.5 \%$ sucrose, and $2 \mathrm{mg}$ of lysozyme per $\mathrm{mL}$ ) and kept for $30 \mathrm{~min}$ at $37^{\circ} \mathrm{C}$. Then, a $200-\mu \mathrm{L}$ aliquot of a lysing solution ( $1 \mathrm{mg} \mathrm{mL}^{-1}$ proteinase $\mathrm{K}$ in $1 \%$ sodium dodecyl sulfate) was added and the mixture was incubated for 2 hours at $37^{\circ} \mathrm{C}$. Thereafter, $70 \mu \mathrm{L}$ of $5 \mathrm{M} \mathrm{NaCl}$ was added and mixed thoroughly and $55 \mu \mathrm{L}$ of $10 \%$ cetyltrimethylammonium bromide (CTAB) solution with $0.7 \mathrm{M}$ of $\mathrm{NaCl}$ were added to remove cell materials such as polysaccharides and kept for $10 \mathrm{~min}$ at $65^{\circ} \mathrm{C}$. The genomic DNA was purified from lysates by phenol-chloroform extraction two times and then precipitated using 2-propanol. The precipitated DNA was washed two times with $70 \%$ ethanol. Finally, it was resuspended in sterilized water purified with a SimPak.1 (Millipore, Billerica, USA) and kept at $4^{\circ} \mathrm{C}$ overnight in order to dissolve. The DNA concentration was checked by spectrophotometer (Ultrospec 3300 pro, GE Healthcare Japan, Hino, Japan).

PCR amplification and sequencing of regions of the nodA and $16 S$ rRNA genes

The nodA and 16S rRNA genes were amplified by PCR using the pairs of primers shown in Fig. 3. The reaction was performed in a mixture of $50 \mu \mathrm{L}$ containing template DNA, 10× enzyme buffer, deoxynucleoside triphosphates (dNTPs), $1 \mu \mathrm{L}$ of the primers $(100$ pmol) and $0.25 \mu \mathrm{L}$ of the enzyme (ExTaq polymerase $5 \mathrm{U} \mathrm{mL}^{-1}$, Takara Bio, Otsu, Japan) according to the manufacturer's manual. Amplification was carried out with the following temperature profile: an initial cycle of denaturation at $94^{\circ} \mathrm{C}$ for $5 \mathrm{~min}, 30$ cycles of denaturation at $94^{\circ} \mathrm{C}$ for $1 \mathrm{~min}$, annealing at $55^{\circ} \mathrm{C}$ for $30 \mathrm{~s}$, and extension at $72^{\circ} \mathrm{C}$ for $3 \mathrm{~min}$, and a final extension at $72^{\circ} \mathrm{C}$ for $7 \mathrm{~min}$. The PCR products were checked by horizontal electrophoresis in a $1 \%(w / v)$ agarose gel with Tris-Acetate-EDTA (TAE) buffer. Subsequently, bands were excised and DNA was purified using a QIAEX II agarose gel extraction kit (Qiagen, Valencia, USA). Prior to sequencing, a nearly full nodA sequence and a partial $16 \mathrm{~S}$ rRNA sequence were subjected to a sequencing reaction with an $\mathrm{ABI}$ Prism Big-Dye terminator v 3.1 cycle sequencing Kit (Applied Biosystems, Foster City, USA) using the same pairs of primers shown in Fig. 3. DNA sequences of the fragments were determined using ABI PRISM 310 and ABI PRISM 3130 genetic analyzers (Applied Biosystems).

\section{Analysis of DNA sequences}

The multiple sequence alignment of nucleotide sequences and boot-strapping for creating N-J phylogenetic trees were performed using Clustal X 1.81 (36) and MEGA 4.0 (35).

\section{Nucleotide sequence accession numbers}

The 16S rRNA and nodA sequences have been deposited in the DNA Data bank of Japan under the accession numbers AB535681AB535712 for 16S rRNA and AB535160-AB535191 for nodA.

\section{Plant test}

To assess the symbiotic abilities of the isolates to generate root nodules on their original host plants, isolates were grown on YM broth for 3 days at $28^{\circ} \mathrm{C}$ and the resulting bacterial cells, approximately $10^{9}$ cells $\mathrm{mL}^{-1}$ determined by a dilution plate count method described by Vincent (40), were inoculated to aseptic Medicago seeds. Plants were grown in a growth chamber with the same conditions indicated previously. Each isolate was tested on triplicate plants and uninoculated control plants were included. Eight weeks later, to evaluate the symbiotic performance of each isolate, ethylene production was evaluated by the acetylene reduction assay according to the method described by Hardy et al. (12). Shoot weight and root nodule numbers in each plant were also determined. For each isolate, the inoculation effect was estimated by determining the relative index of dry weight increase according to the following formula: relative index of dry weight increase= (inoculated plant dry weight)/(control plant dry weight). Additionally, four isolates corresponding to the most stress-tolerant isolates originating from the four Medicago species were further tested for symbiotic efficiency in cross inoculation tests. Plant inoculation and growth conditions were as above and uninoculated control treatments were included. After 6 weeks of growth, nodulation was recorded by the existence of nodules and the efficiency was estimated by the presence of red coloring (leghemoglobin) inside the nodules (40).

\section{Results}

\section{Isolation of rhizobia from Medicago species}

A total of 256 isolates were isolated from root nodules of four Medicago species. The repartition of these isolates according
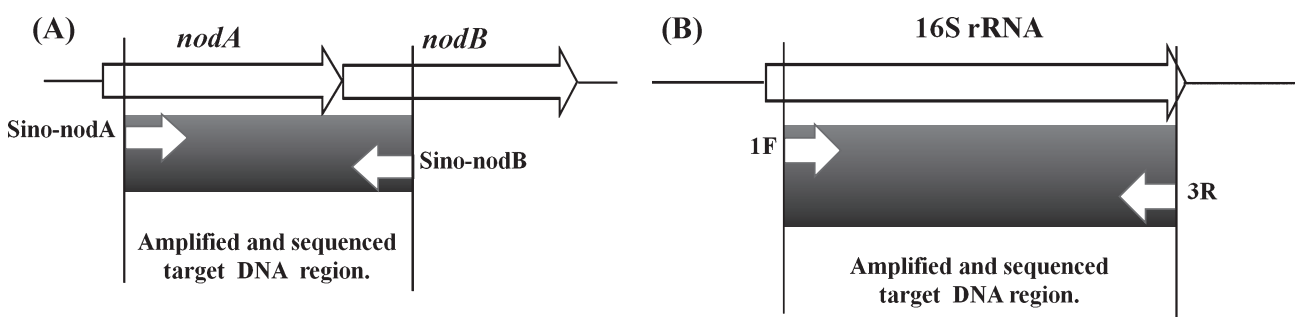

Fig. 3. Pairs of primers used for PCR amplification and sequencing of the nodA (A) and 16S rRNA genes (B). A: Sino-nodA (TGCRGTGGAAR NTRNNCTGGGAAA), start: nucleotide 14 of nodA, end: nucleotide 38 of nodA gene sequence of E. meliloti; Sino-nodB (GGNCCGTC RAAWGTCARGTA), Start: nucleotide 88 of nodB, end: nucleotide 66 of nodB gene sequence of $E$. meliloti. B: 1F (AGTTTGATCCTGGCTC), start: nucleotide 11 of 16S rRNA, end: nucleotide 26 of 16S rRNA gene sequence of Escherichia coli; 3R (AAGGAGGTGATCCAGCC), start: nucleotide 1489 of 16S rRNA, end: nucleotide 1472 of 16S rRNA gene sequence of Escherichia coli. 
Table 1. Summary of polyphasic analysis

\begin{tabular}{|c|c|c|c|c|c|c|c|c|c|c|c|}
\hline \multirow[b]{2}{*}{ Isolates $^{\mathrm{a}}$} & \multirow[b]{2}{*}{$\begin{array}{l}\text { Host } \\
\text { plants }\end{array}$} & \multirow[b]{2}{*}{$\begin{array}{l}\text { Geographic } \\
\text { Origins }\end{array}$} & \multicolumn{4}{|c|}{ Stress tolerance } & \multicolumn{4}{|c|}{ Phylogenetic properties } & \multirow[b]{2}{*}{$\begin{array}{l}\text { Indexes of } \\
\text { dry weight } \\
\text { increase** }\end{array}$} \\
\hline & & & $\begin{array}{l}\text { Temperature } \\
\text { range }\end{array}$ & $\begin{array}{l}\mathrm{NaCl} \\
(\%)^{*}\end{array}$ & $\mathrm{pH}^{*}$ & $\begin{array}{l}\text { Drought } \\
\text { PEG* }^{*}\end{array}$ & $\begin{array}{c}\text { 16S-rRNA } \\
\text { group }\end{array}$ & Species & $\begin{array}{l}\text { nodA } \\
\text { group }\end{array}$ & $\begin{array}{l}\text { Origin of } \\
\text { nodulation } \\
\text { genes }\end{array}$ & \\
\hline St.1-2 & M. sativa & Sub-humid & $28-40^{\circ} \mathrm{C}$ & $2 \%(++)$ & $10.5(+)$ & $25 \%(+)$ & GIV & E. meliloti & GVII & Ensifer & 6.2 \\
\hline St.1-3 & M. sativa & Sub-humid & $28-40^{\circ} \mathrm{C}$ & $4 \%(+)$ & $10.5(++)$ & $25 \%(+)$ & GIV & E. meliloti & GVII & Ensifer & 9.8 \\
\hline St.1-15 & M. sativa & Sub-humid & $28-40^{\circ} \mathrm{C}$ & $3 \%(++)$ & $10.5(+)$ & $25 \%(+)$ & GIV & E. meliloti & GVI & Ensifer & 7.3 \\
\hline St.2-5 & M. sativa & Sup. Semiarid & $28-40^{\circ} \mathrm{C}$ & $2 \%(++)$ & $10.5(+)$ & $25 \%(+)$ & GIV & E. meliloti & GVII & Ensifer & 7.5 \\
\hline St.2-6 & M. sativa & Sup. Semiarid & $28-45^{\circ} \mathrm{C}$ & $3 \%(+)$ & $9(+)$ & $25 \%(+)$ & GIV & E. meliloti & GVI & Ensifer & 8.3 \\
\hline St.3-1 & M. sativa & Sup. Semiarid & $28-45^{\circ} \mathrm{C}$ & $3 \%(+)$ & $9(+)$ & $25 \%(+)$ & GIV & E. meliloti & GVI & Ensifer & 6.2 \\
\hline St.3-7 & M. sativa & Sup. Semiarid & $28-40^{\circ} \mathrm{C}$ & $2 \%(++)$ & $10.5(+)$ & $25 \%(+)$ & GIV & E. meliloti & GVI & Ensifer & 5 \\
\hline St.3-13 & M. sativa & Sup. Semiarid & $28-40^{\circ} \mathrm{C}$ & $4 \%(+)$ & $10.5(+)$ & $25 \%(+)$ & GII & A. tumefaciens*** & GVI & Ensifer & 5.7 \\
\hline St.4-2 & M. sativa & Inf. Semiarid & $28-45^{\circ} \mathrm{C}$ & $2 \%(++)$ & $10.5(+)$ & $25 \%(+)$ & GIV & E. meliloti & GVI & Ensifer & 7.7 \\
\hline St.4-5 & M. sativa & Inf. semiarid & $28-40^{\circ} \mathrm{C}$ & $2 \%(++)$ & $10.5(+)$ & $25 \%(+)$ & GIV & E. meliloti & GVI & Ensifer & 9.1 \\
\hline St.4-14 & M. sativa & Inf. semiarid & $28-45^{\circ} \mathrm{C}$ & $2 \%(++)$ & $9(+)$ & $25 \%(+)$ & GIV & E. meliloti & GVI & Ensifer & 4.9 \\
\hline St. $5-10$ & M. sativa & Arid & $28-45^{\circ} \mathrm{C}$ & $2 \%(++)$ & $10.5(+)$ & $25 \%(+)$ & GIV & E. meliloti & GVIII & E. meliloti & 3.6 \\
\hline Cl.1-14 & M. ciliaris & Sub-humid & $28-40^{\circ} \mathrm{C}$ & $3 \%(+)$ & $10.5(+)$ & $25 \%(+)$ & GVI & E. medicae & GX & E. medicae & 2.2 \\
\hline Cl.2-12 & M. ciliaris & Sup. Semiarid & $28-40^{\circ} \mathrm{C}$ & $1 \%(+++)$ & $9(++)$ & $25 \%(+)$ & GIV & E. meliloti & GVII & Ensifer & 2.9 \\
\hline Cl.3-1 & M. ciliaris & Sup. Semiarid & $28-40^{\circ} \mathrm{C}$ & $2 \%(+)$ & $10.5(+)$ & $25 \%(+)$ & GVI & E. medicae & GX & E. medicae & 2.1 \\
\hline Cl.3-2 & M. ciliaris & Sup. Semiarid & $28-40^{\circ} \mathrm{C}$ & $2 \%(+)$ & $10.5(+)$ & $25 \%(+)$ & GVI & E. medicae & GX & E. medicae & 1.7 \\
\hline Cl.4-7 & M. ciliaris & Inf. Semiarid & $28-45^{\circ} \mathrm{C}$ & $2 \%(+)$ & $9(+)$ & $25 \%(+)$ & GIV & E. meliloti & GVI & Ensifer & 2 \\
\hline Cl.4-10 & M. ciliaris & Inf. Semiarid & $28-45^{\circ} \mathrm{C}$ & $3 \%(+)$ & $10.5(+)$ & $15 \%(+)$ & GIV & E. meliloti & GVI & Ensifer & 1.4 \\
\hline Cl.4-12 & M. ciliaris & Inf. Semiarid & $28-45^{\circ} \mathrm{C}$ & $2 \%(++)$ & $10.5(+)$ & $15 \%(+)$ & GIV & E. meliloti & GIX & Ensifer & 1.5 \\
\hline Pl.2-1 & M. polymorpha & Sup. Semiarid & $28-40^{\circ} \mathrm{C}$ & $3 \%(++)$ & $9(+)$ & $25 \%(+)$ & GII & A. tumefaciens**** & GX & E. medicae & 1.2 \\
\hline Pl.3-6 & M. polymorpha & Sup. Semiarid & $28-40^{\circ} \mathrm{C}$ & $3 \%(+)$ & $10.5(+)$ & $25 \%(+)$ & GII & A. tumefaciens $* * * *$ & GX & E. medicae & 4 \\
\hline Pl.3-9 & M. polymorpha & Sup. Semiarid & $28-40^{\circ} \mathrm{C}$ & $3 \%(+)$ & $10.5(+)$ & $25 \%(+)$ & GIV & E. meliloti & GX & E. medicae & 2.5 \\
\hline Pl.4-2 & M. polymorpha & Inf. semiarid & $28-37^{\circ} \mathrm{C}$ & $1 \%(++)$ & $9(+)$ & $25 \%(+)$ & GVI & E. medicae & GXI & Ensifer & 7.5 \\
\hline Mn.2-8 & M. minima & Sup. Semiarid & $28-40^{\circ} \mathrm{C}$ & $2 \%(+)$ & $10.5(++)$ & $25 \%(+)$ & GIV & E. meliloti & GVII & Ensifer & 3.3 \\
\hline Mn.3-1 & M. minima & Sup. Semiarid & $28-40^{\circ} \mathrm{C}$ & $3 \%(+)$ & $10.5(+)$ & $25 \%(+)$ & GIV & E. meliloti & GVI & Ensifer & 3.1 \\
\hline Mn.3-12 & M. minima & Sup. Semiarid & $28-40^{\circ} \mathrm{C}$ & $2 \%(++)$ & $10.5(+)$ & $25 \%(+)$ & GIV & E. meliloti & GVI & Ensifer & 3.2 \\
\hline Mn.4-1 & M. minima & Inf. semiarid & $28-45^{\circ} \mathrm{C}$ & $3 \%(+)$ & $10.5(++)$ & $25 \%(+)$ & GIV & E. meliloti & GVI & Ensifer & 3.6 \\
\hline Mn.4-4 & M. minima & Inf. semiarid & $28-45^{\circ} \mathrm{C}$ & $2 \%(++)$ & $10.5(++)$ & $25 \%(+)$ & GIV & E. meliloti & GVI & Ensifer & 6.7 \\
\hline Mn.4-9 & M. minima & Inf. semiarid & $28-45^{\circ} \mathrm{C}$ & $2 \%(++)$ & $10.5(++)$ & $25 \%(+)$ & GIV & E. meliloti & GVI & Ensifer & 6.5 \\
\hline Mn.4-18 & M. minima & Inf. semiarid & $28-40^{\circ} \mathrm{C}$ & $2 \%(++)$ & $10.5(+)$ & $25 \%(+)$ & GIV & E. meliloti & GVI & Ensifer & 3 \\
\hline Mn.5-1 & M. minima & Arid & $28-40^{\circ} \mathrm{C}$ & $2 \%(++)$ & $10.5(+)$ & $25 \%(+)$ & GIV & E. meliloti & GIV & unknown & 4.3 \\
\hline Mn.5-4 & M. minima & Arid & $28-40^{\circ} \mathrm{C}$ & $2 \%(++)$ & $10.5(+)$ & $25 \%(+)$ & GIV & E. meliloti & GVII & Ensifer & 3.1 \\
\hline
\end{tabular}

* Growth scores were recorded as follows: -, no growth; +, weak growth (10-30\% in relation to the control); ++, good growth (30-80\% in relation to the control); and +++, very good growth (similar to the control); ** effects relative to the control were determined in terms of plant dry weight; *** this isolate showed horizontal gene transfer from Sinorhizobium to A. tumefaciens; **** these isolates showed horizontal gene transfers from S. medicae to A. tumefaciens. a the two letters in the isolate names indicate the host plant of origin (St: M. sativa, Cl: M. ciliaris, Pl: M. polymorpha and Mn: M. minima), the number following the letters indicates the soil of origin of the isolate (soil sample number in Fig. 1) and the last number indicates the isolate reference number.

to the host plants was as follows: ninety six isolates from Medicago sativa, sixty from Medicago ciliaris, sixty from Medicago polymorpha and forty from Medicago minima with combinations of five different soils covering several bioclimatic regions of Tunisia. All isolates had the same colony morphology and produced transparent and creamy colonies when grown on YM plates at $28^{\circ} \mathrm{C}$. Almost all the isolates tested were fast growers, their colonies reaching $2 \mathrm{~mm}$ in diameter after 4 to 5 days at $28^{\circ} \mathrm{C}$.

Classification of isolates based on differences in stress resistances under different salt concentrations, $p H$, temperatures and PEG 6000 concentrations

The 256 isolates were first screened for resistance to high salinity, alkaline $\mathrm{pH}$, high drought and high temperature conditions as described in Fig. 2. According to this preliminary characterization, high diversity in stress resistance was observed among the 256 isolates. In the high salinity test, only two isolates from $M$. sativa (about $2 \%$ of the isolates from this plant) were able to grow at $4 \%$ $\mathrm{NaCl}$, while at $3 \% \mathrm{NaCl}$, the percentage of tolerant isolates was $25 \%$ for M. sativa, $26.6 \%$ for M. ciliaris, $26.6 \%$ for M. polymorpha and $42.5 \%$ for $M$. minima. Regarding high temperature resistance, $5.2 \%$ of the isolates from M. sativa, $5 \%$ from M. ciliaris and $7.5 \%$ from M. minima were able to grow at $45^{\circ} \mathrm{C}$, however none of the isolates obtained from $M$. polymorpha survived at this temperature. Similarly, most of the isolates tolerated a $\mathrm{pH}$ of 10.5 : i.e. $70 \%$ of $M$. sativa isolates, $75 \%$ of $M$. ciliaris isolates, $66.6 \%$ of M. polymorpha isolates and $72.5 \%$ of $M$. minima isolates. Similarly, almost the same percentages of tolerant isolates were recorded in the drought stress test with $25 \%$ PEG 6000.

Twelve isolates from M. sativa, seven from M. ciliaris, four from M. polymorpha and nine from M. minima were selected based on stress resistance as shown in Table 1 . To confirm their resistance, these 32 isolates were subjected to the same stress test described previously.

Concerning high temperature resistance, all the isolates tested grew at $40^{\circ} \mathrm{C}$ with one exception, P1.4-2. Five isolates from $M$. sativa, three from $M$. ciliaris and three from M. minima survived at $45^{\circ} \mathrm{C}$. However, none of the four isolates from M. polymorpha survived at $45^{\circ} \mathrm{C}$.

Regarding high salt resistance, only two isolates obtained from 
Table 2. Reference strains used in this study

\begin{tabular}{|c|c|c|}
\hline Species/strains & Source & Reference \\
\hline \multicolumn{3}{|l|}{ Agrobacterium tumefaciens } \\
\hline C 58 & Prunus sp., United States & 26 \\
\hline CCBAU 85015 & Caragana sinica, China & 13 \\
\hline \multicolumn{3}{|l|}{ Ensifer adhaerens } \\
\hline LMG $20216^{\mathrm{T}}$ & Soil, United States & 20 \\
\hline ORS 529 & Lotus arabicus, Senegal & 21 \\
\hline \multicolumn{3}{|l|}{ Ensifer arboris } \\
\hline $\begin{array}{l}\text { LMG } 14919^{\mathrm{T}} \\
\left(=\text { HAMBI } 1552^{\mathrm{T}}\right)\end{array}$ & Prosopis chilensis, Sudan & 20 \\
\hline \multicolumn{3}{|l|}{ Ensifer fredii } \\
\hline USDA $205^{\mathrm{T}}$ & Glycine max, China & 20 \\
\hline \multicolumn{3}{|l|}{ Ensifer garamanticus } \\
\hline ORS $1400^{\mathrm{T}}$ & $\begin{array}{l}\text { Argyrolobium uniflorum, } \\
\text { Tunisia }\end{array}$ & 21 \\
\hline \multicolumn{3}{|l|}{ Ensifer medicae } \\
\hline $\mathrm{A} 321^{\mathrm{T}}$ & Medicago truncatula, France & 20 \\
\hline WSM419 & Medicago murex, Italy & 10 \\
\hline \multicolumn{3}{|l|}{ Ensifer meliloti } \\
\hline 1021 & Medicago sativa, Australia & 9 \\
\hline USDA $1002^{\mathrm{T}}$ & Medicago sativa, United States & 24 \\
\hline LMG $6133^{\mathrm{T}}$ & Medicago sativa, United States & 20 \\
\hline \multicolumn{3}{|l|}{ Ensifer numidicus } \\
\hline ORS $1444^{\mathrm{T}}$ & $\begin{array}{l}\text { Argyrolobium uniflorum, } \\
\text { Tunisia }\end{array}$ & 21 \\
\hline \multicolumn{3}{|l|}{ Ensifer saheli } \\
\hline LMG $7837^{\mathrm{T}}\left(=\right.$ ORS $\left.609^{\mathrm{T}}\right)$ & Sesbania cannabina, Senegal & 20 \\
\hline \multicolumn{3}{|l|}{ Ensifer species } \\
\hline ORS $1407^{\mathrm{T}}$ & $\begin{array}{l}\text { Argyrolobium uniflorum, } \\
\text { Tunisia }\end{array}$ & 21 \\
\hline \multicolumn{3}{|l|}{ Rhizobium etli } \\
\hline $\mathrm{CNF} 42^{\mathrm{T}}$ & Phaseolus vulgaris, Mexico & 24 \\
\hline \multicolumn{3}{|l|}{ Rhizobium mongolens } \\
\hline USDA $1844^{\mathrm{T}}$ & Medicago ruthenica, China & 37 \\
\hline \multicolumn{3}{|l|}{ Rhizobium species } \\
\hline Glm 16 & Glycine max, Korea & 18 \\
\hline
\end{tabular}

M. sativa were able to grow at $4 \% \mathrm{NaCl}$ as shown in Table 1 . At $3 \%$ $\mathrm{NaCl}$, five isolates from $M$. sativa, two from M. ciliaris, three from M. polymorpha and two from M. minima were able to grow.

In the case of high $\mathrm{pH}$ resistance, almost all the isolates tested were able to grow at $\mathrm{pH} 9$ and 25 isolates survived at $\mathrm{pH} 10.5$ as shown in Table 1. Similarly, in the case of drought resistance, nearly all isolates survived at $25 \%$ PEG 6000 with the exception of Cl.4-10 and Cl.4-12 from M. ciliaris.

Phylogenetic analysis of the 32 isolates in terms of differences in $16 S$ rRNA gene sequences

The nearly entire sequence of the 16S rRNA gene of the 32 isolates was phylogenetically analyzed using the Neighbour-joining method (28). The 32 isolates and 15 reference strains (Table 2) were classified into 9 groups shown in Fig. 4. R. etli CFN $42^{\mathrm{T}}$ and $R$. mongolense USDA $1844^{\mathrm{T}}$ were classified into GI without any isolate from this study. Similarly, E. fredii USDA205 ${ }^{\mathrm{T}}$ and E. saheli LMG $7837^{\mathrm{T}}$ were classified into GVIII and no isolates existed in this group. E. sp. ORS $1400^{\mathrm{T}}$, E. sp. ORS $1407^{\mathrm{T}}$, E. arboris LMG $14919^{\mathrm{T}}$ and E. adhaerens LMG $20216^{\mathrm{T}}$ consisted of singletons named GIII, GV, GVII and GIX, respectively. Pl.2-1, P1.3-6 and St.3-13 from M. polymorpha and M. sativa were classified into GII and this group included $A$. tumefaciens CCBAU85015 and $A$. tumefaciens C58. The 16S rRNA gene St.3-13 was identical in sequence to $A$. tumefaciens $\mathrm{C} 58$ and the $16 \mathrm{~S}$ rRNA genes of P1.2-1 and Pl.3-6 were 99\% similar to A. tumefaciens CCBAU85015. Twenty five isolates were classified into GIV with the reference strains E. meliloti 1021 and E. meliloti LMG $6133^{\mathrm{T}}$. The $16 \mathrm{~S}$ rRNA genes of these isolates and reference strains were 99.7 to $100 \%$ similar. Therefore, these isolates had close relationships to $E$. meliloti. Three isolates obtained from M. ciliaris and one from M. polymorpha were grouped into GVI. This group contained 2 reference strains of $E$. medicae. Therefore, these 4 isolates had close relationships to E. medicae. Notably, the $16 \mathrm{~S}$ rRNA sequences of Cl.1-14, Cl.3-1 and Pl.4-2 were identical to those of E. medicae WSM419 and E. medicae A321 ${ }^{\mathrm{T}}$.

\section{Phylogenetic analysis of the 32 isolates in terms of differences in nodA gene sequences}

The 32 isolates and 12 references strains (Table 2) were classified into 13 groups as shown in Fig. 5. GI only consisted of the reference strains $E$. fredii USDA205 ${ }^{\mathrm{T}}$ and $R$. etli $\mathrm{CNF} 42^{\mathrm{T}}$, while $\mathrm{GV}$ consisted of E. nimidicus ORS1444 ${ }^{\mathrm{T}}$ and E. garamanticus ORS1400 ${ }^{\mathrm{T}}$. E. saheli ORS $609^{\mathrm{T}}$, E. arboris HAMBI $1552^{\mathrm{T}}$, E. meliloti 1021 and $R$. mongolense USDA $1844^{\mathrm{T}}$ consisted of singletons, named GII, GIII, GXII and GXIII, respectively. Sixteen isolates from $M$. sativa, $M$. ciliaris and M. minima were classified into GVI but there were no reference strains in this group. GVII comprised 6 isolates from M. sativa, M. minima and M. ciliaris without any reference strains. One isolate of St.5-10 was grouped into GVIII with the reference strain E. meliloti USDA1002 ${ }^{\mathrm{T}}$, and DNA sequence of this isolate was $99 \%$ similar to that of the reference strain. Two isolates, Cl.4-12 and Pl.4-2, consisted of singletons. The remaining 6 isolates were categorized into GX with 2 references strains assigned to $E$. medicae. DNA sequences of the 6 isolates were identical to that of E. medicae WSM419 and $E$. medicae $\mathrm{A} 321^{\mathrm{T}}$ which is a type strain of E. medicae. The 16S-rRNA gene sequences of isolates categorized into GVI, GVII, GVIII and GIX had a close relationship to those of E. meliloti as shown in Figs. 4 and 5 with the exception of one isolate, St.3-13. This means that $E$. meliloti had extensive genetic diversity in terms of DNA sequences of nodA. Concerning GX, 3 isolates were categorized into E. medicae based on DNA sequences of the 16S rRNA gene. Interestingly, the remaining 3 isolates of this group were assigned to A. tumefaciens and E. meliloti.

\section{Plant tests}

The 32 isolates were tested for their capacity to form root nodules on their original host plants under controlled laboratory conditions of temperature and relative humidity. All the isolates induced root nodules to form on their original hosts, and the uninoculated plants used as negative controls were not nodulated as shown in Fig. 6. Root nodule numbers in the original host plants, are shown in Fig. 6-A. The mean number varied from 6 in Mn.5-1 to 44 in $\mathrm{Cl} .2-12$. Isolates from $M$. ciliaris formed more root nodules than the other isolates. In general, the isolates from M. minima formed fewer nodules. Three isolates, St.3-13, Pl.2-1 and Pl.2-6, categorized as $A$. tumefaciens based on $16 \mathrm{~S}$ rRNA sequences clearly showed nodulation in the original host plants.

The acetylene reducing activities of the 32 isolates when applied to their original host plants respectively are shown in Fig. 6-B. One isolate from M. sativa (St.3-1) displayed the highest level of activity. This isolate was assigned to E. meliloti according to 16 rRNA gene sequencing. St.3-13, Pl.2-1 and Pl.3-6 categorized as A. tumefaciens displayed acetylene reduction activities which were not significantly different in comparison with the remaining isolates classified into E. meliloti or E. medicae, except for St.3-1 as shown in Fig. 6-B.

Relative indexes of dry weight increase in original host plants inoculated with the 32 isolates are shown in Fig. 7. Generally, inoculations of isolates obtained from $M$. sativa to the original host plants had clearly induced increases of shoot dry weights. The relative indexes with isolates obtained from M. sativa were higher than those of remaining isolates.

The symbiotic effectiveness of the four Medicago species with a sample of four isolates representing the most stress tolerant isolates 


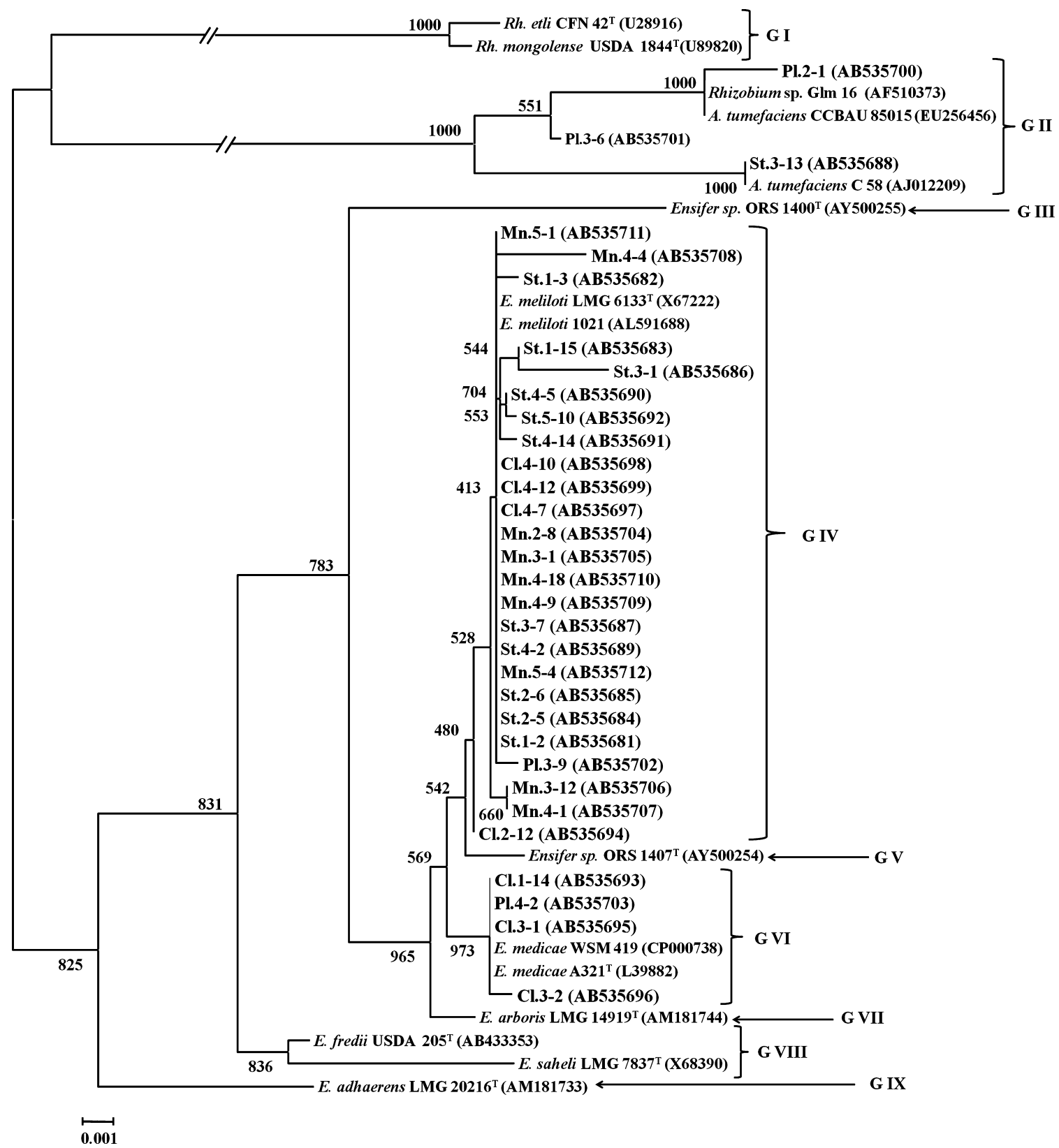

Fig. 4. Phylogenetic tree derived from neighbour-joining analysis of 1400-bp 16S rRNA sequences from Medicago nodulating isolates and 15 representative type strains from GenBank: Agrobacterium tumefaciens C58, Agrobacterium tumefaciens CCBAU85015, E. adhaerens LMG $20216^{\mathrm{T}}$, E. arboris LMG $14919^{\mathrm{T}}$, E. fredii USDA205 ${ }^{\mathrm{T}}$, E. medicae $\mathrm{A} 321^{\mathrm{T}}$, E. medicae WSM419, E. meliloti 1021 , E. meliloti $\mathrm{LMG}^{6} 6133^{\mathrm{T}}$, E. saheli LMG7837 ${ }^{\mathrm{T}}, E$. sp. ORS $1400^{\mathrm{T}}, E$. sp. ORS $1407^{\mathrm{T}}, R$. etli CNF $42^{\mathrm{T}}, R$. mongolense USDA $1844^{\mathrm{T}}$ and $R$. sp. GLM16.

The numbers at the branch nodes indicate bootstrap values based on 1000 replicates. The scale bar indicates substitutions per site.

(salinity and high temperature especially) was estimated. The four isolates selected for this cross inoculation test were St.1-3, Cl.4-10, Pl.3-9 and Mn.4-1 from M. sativa, M. ciliaris, M. polymorpha and M. minima, respectively (Table 3). Each isolate was able to nodulate and fix nitrogen efficiently when applied to its host plant and none of the four isolates was effective with the four Medicago species. Three isolates from M. sativa, M. ciliaris and M. minima (St.1-3, Cl.4-10 and Mn.4-1) with a nodA originating from Ensifer species (according to sequencing of the nodA region) were able to form effective nodules (estimated by the red color of nodules) on $M$. sativa, M. ciliaris and M. minima. Though, in the case of $M$. polymorpha, only ineffective nodules characterized by a white color were observed when three previous isolates were applied to this plant. Additionally, in the case of P1.3-9 from M. polymorpha with a nodA gene sequence categorized as E. medicae, effective nodules were observed only when this isolate was applied to M. ciliaris. However this isolate from M. polymorpha was ineffective when applied to M. sativa and M. minima.

\section{Discussion}

Symbiotic relationship among 4 Medicago species and Ensifer

In Tunisia, $M$. sativa is widely cultivated, $M$. ciliaris is widely distributed from humid to semi-arid climatic zones and M. minima and M. polymorpha are distributed from semi-arid to saharian climatic zones. To obtain Ensifer isolates, these four Medicago species were used in combination with five soil samples collected from different climatic zones in Tunisia. Consequently, a total of 256 isolates was isolated from root nodules. Based on differences 


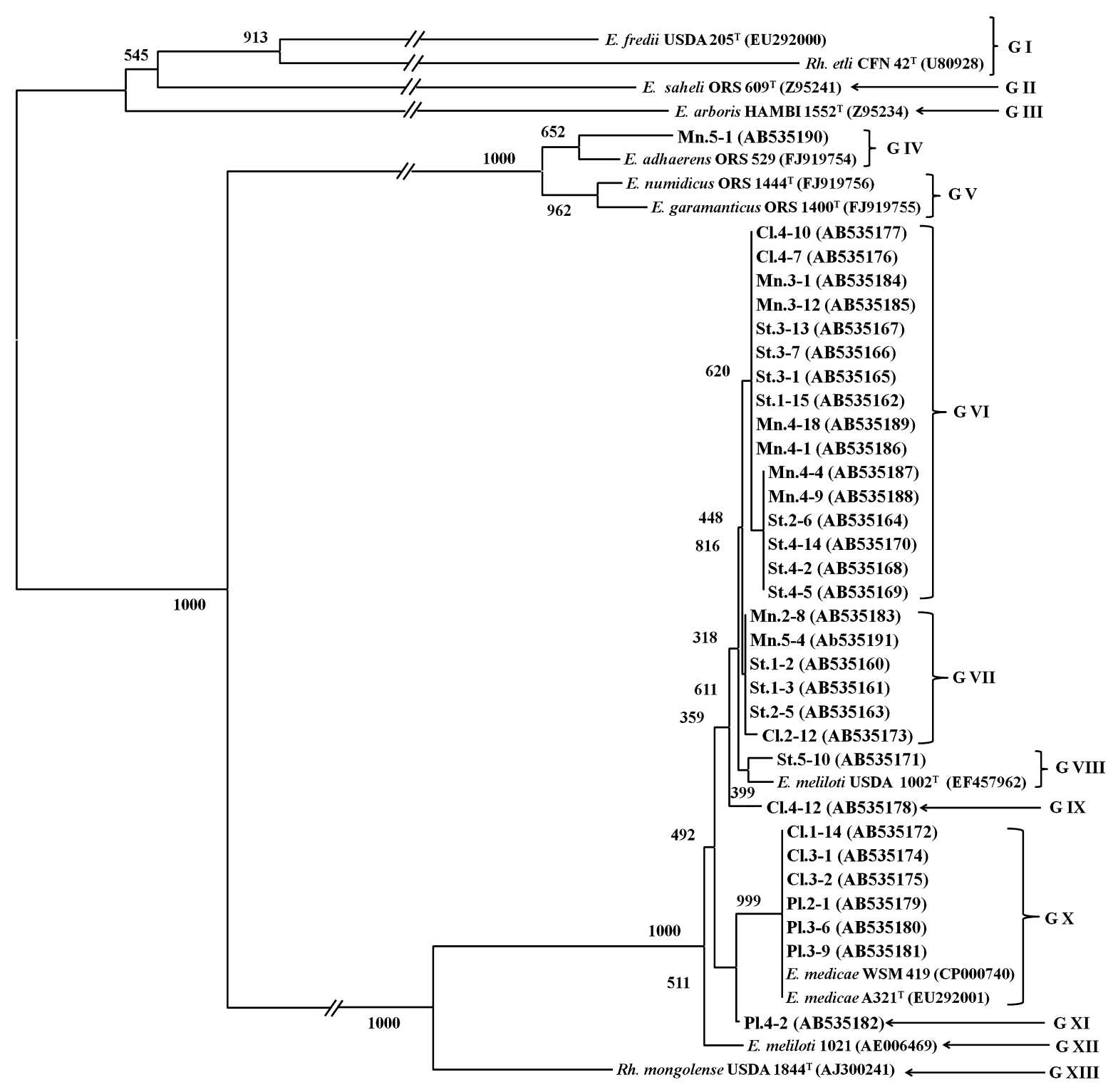

$\stackrel{\longmapsto 005}{\longrightarrow}$

Fig. 5. Neighbour-joining tree of nodA gene sequences of root nodule bacteria associated with Medicago species. Twelve representative type strains from GenBank were used as references: E. adhaerans ORS529, E. arboris HAMBI $1552^{\mathrm{T}}$, E. fredii USDA205 ${ }^{\mathrm{T}}$, E. garamanticus $\mathrm{ORS}_{1400^{\mathrm{T}}}$, E. medicae A321 ${ }^{\mathrm{T}}$, E. medicae WSM419, E. meliloti 1021, E. meliloti USDA $1002^{\mathrm{T}}$, E. nimidicus $\mathrm{ORS} 1444^{\mathrm{T}}$, E. saheli ORS $609^{\mathrm{T}}$, R. etli CNF $42^{\mathrm{T}}$, and $R$. mongolense USDA $1844^{\mathrm{T}}$.

The numbers at the branch nodes indicate bootstrap values based on 1,000 replicates. The scale bar indicates substitutions per site.

in high salinity, alkaline $\mathrm{pH}$, high temperature and drought stress resistance, we selected 32 isolates as shown in Table 1.

Based on frequencies of Ensifer species from root nodules of each host plant, $M$. sativa and M. minima show a preference for E. meliloti. Concerning the symbiotic partner of M. minima, Sebbane et al. (29) first isolated E. meliloti from root nodules of M. minima in Algeria. We also confirmed that E. meliloti seems to be the predominant symbiont of M. minima in Tunisia. In contrast, $M$. ciliaris has a preference for E. medicae. In the case of $M$. polymorpha, out of four isolates, two were categorized as $A$. tumefaciens and one each as E. meliloti and E. medicae, respectively. Van Berkum et al. (38) reported that the predominant symbiont of M. polymorpha is E. medicae.

Relationship between high salt and high temperature resistance of Ensifer isolates and their geographical origin

To isolate Ensifer isolates, we used five different soil samples from four bioclimatic regions (Fig. 1). Accordingly, we found that $M$. sativa is one of the best trap hosts to isolate Ensifer displaying high abiotic stress resistances as indicated in Table 2. In the case of high salt resistance, St.1-3 and St.3-13 from M. sativa survived at $4 \% \mathrm{NaCl}$. Shamseldin et al. (32) reported that E. meliloti strains from faba bean root nodules survived at $3 \% \mathrm{NaCl}$. Payakapong et al. (25) also reported that an Ensifer strain of BL3 obtained from root nodules of Phaseolus lathyroides could survive at $3.5 \% \mathrm{NaCl}$. Shamseldin et al. (31) reported the proteomic characterization of Rhizobium etli at $4 \% \mathrm{NaCl}$. In the case of high temperature resistance, out of 32 isolates, eleven isolates survived at $45^{\circ} \mathrm{C}$ as shown in Table 2. Concerning high temperature resistance, some tolerant rhizobial isolates have been described. For instance, Fall et al. (8) isolated rhizobia from Acacia senegal that showed good growth at $45^{\circ} \mathrm{C}$. Furthermore, Ge-Hong et al. (11) reported a temperature tolerant strain of Mesorhizobium at $35^{\circ} \mathrm{C}$. However, there is no report about E. meliloti surviving at $45^{\circ} \mathrm{C}$. Interestingly, out of the 
A: Root nodule numbers
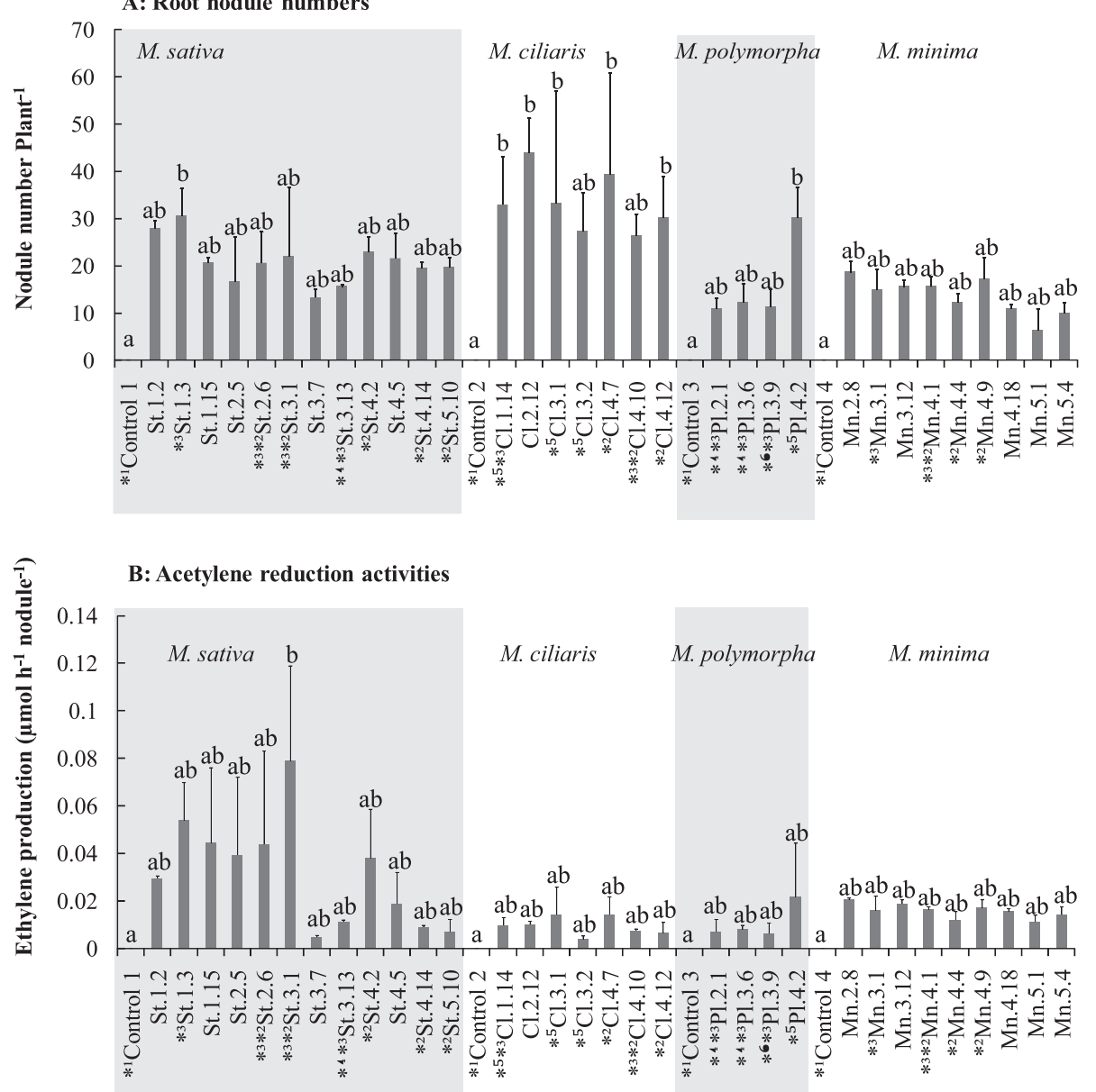

Fig. 6. Root nodule numbers and Acetylen reduction assay of Medicago plants inoculated with the 32 isolates. *1: uninoculated control plants, $* 2$ : isolates with high temperature tolerance, $* 3$ : isolates with high salinity tolerance, $* 4$ : isolates categorized as A. tumefaciens, $* 5$ : isolates assigned to $E$. medicae, *6: isolate categorized as E. meliloti; however, the sequence of nodA was identical to that of $E$. medicae. Different small letters on histograms represent statistically significant differences at $P<0.05$ based on the Tukey-Kramer test.

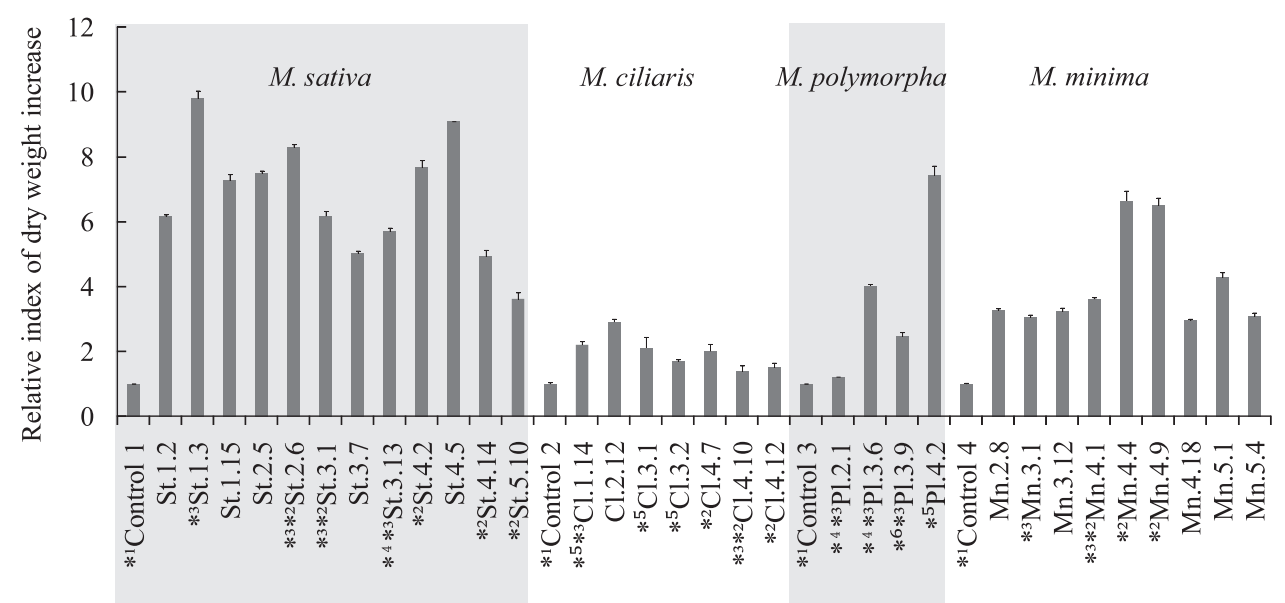

Fig. 7. Relative indexes of dry weight increase when the 32 isolates were applied to their original host plants, respectively: relative index of dry weight increase $=($ inoculated plants dry weights $(\mathrm{mg})) /($ control plants dry weights $(\mathrm{mg})),{ }^{*} 1$ : uninoculated control plants, $* 2$ : isolates with high temperature tolerance, $* 3$ : isolates with high salinity tolerance, $* 4$ : isolates categorized as A. tumefaciens, $* 5$ : isolates assigned to E. medicae, $* 6$ : isolate categorized as E. meliloti; however, the sequence of nodA was identical to that of $E$. medicae.

eleven isolates, five were obtained from root nodules of $M$. sativa shown in Table 1; this also confirmed that M. sativa is a useful trap host to isolate Ensifer having high abiotic stress resistance. For Ensifer isolation, we used five different soils from four climatic zones in Tunisia, sub-humid, superior semi-arid, inferior semi-arid and arid zones. The geographic origins of these eleven isolates were all categorized into superior semi-arid, inferior semi-arid and arid zones. This suggests that the distribution of Ensifer with resistance 
Table 3. Cross inoculation tests of most stress tolerant isolates from Medicago species

\begin{tabular}{|c|c|c|c|c|c|c|}
\hline \multirow{2}{*}{ Isolate } & \multirow{2}{*}{ Original host } & \multirow{2}{*}{$\begin{array}{l}\text { Origin of nodulation } \\
\text { genes }(\operatorname{nod} A)\end{array}$} & \multicolumn{4}{|c|}{ Nodulation and nitrogen fixation on host plant ${ }^{\mathrm{a}}$} \\
\hline & & & M. sativa & M. cilaris & M. polymorpha & M. minima \\
\hline Control & & & nod-/fix- & nod-/fix- & nod-/fix- & nod-/fix- \\
\hline St.1-3 & M. sativa & Ensifer species & nod $+/$ fix + & nod $+/$ fix + & nod $+/$ fix - & nod $+/$ fix + \\
\hline Cl.4-10 & M. cilaris & Ensifer species & nod+/fix + & $\operatorname{nod}+/$ fix + & nod+/fix- & nod $+/$ fix + \\
\hline Pl.3-9 & M. polymorpha & Ensifer medicae & nod $+/$ fix - & $\operatorname{nod}+/$ fix + & nod $+/$ fix + & $\operatorname{nod}+/$ fix - \\
\hline Mn.4-1 & M. minima & Ensifer species & nod $+/$ fix + & nod+/fix + & nod $+/$ fix - & nod $+/$ fix + \\
\hline
\end{tabular}

a: nod-, no nodules; fix-, inefficient nodules (white color); fix+, efficient nodules (red color).

to high temperature is closely related to climatic conditions.

Moreover, four isolates, St.2-6, St.3-1, Cl.4-10 and Mn.4-1, survived at both $45^{\circ} \mathrm{C}$ and $3 \% \mathrm{NaCl}$. Nonetheless, we could not find an isolate able to survive abilities at $45^{\circ} \mathrm{C}$ and $4 \% \mathrm{NaCl}$. Out of these 256 isolates, only $4(1.6 \%$ of the total $)$ could survive at both $45^{\circ} \mathrm{C}$ and $3 \% \mathrm{NaCl}$ as shown in Table 1 . This shows that the frequency of isolates having both high temperature resistance and high salt resistance is low. Therefore, this finding suggests that in order to look for suitable inoculants with multi-tolerance of temperature and salinity for leguminous crops located in semi-arid and arid areas, a large number of isolates is needed.

Relationship between horizontal transfer of symbiotic genes and symbiotic Agrobacterium isolates producing effective root nodules in Medicago species

Based on sequencing of the 16S rRNA genes of 32 isolates, 25 isolates were categorized as E. meliloti and 4 isolates were assigned to $E$. medicae. However, the remaining three isolates were categorized as A. tumefaciens (Fig. 4 and Table 1). Furthermore, to confirm the 16S rRNA and nodA sequences of these isolates, we performed additional analysis. We confirmed that the nodA sequences of Pl.2-1 and P1.3-6 were identical to that of E. medicae, while the nodA sequence of St.3-13 was categorized into Ensifer species as shown in Fig. 5. These results suggest that horizontal gene transfer occurred between Ensifer and A. tumefaciens. In the case of Pl.2-1 and Pl.3-6, it seems that symbiotic genes of $E$. medicae were transferred into A. tumefaciens. Whereas, in the case of St.3-13, it seems that symbiotic genes of Ensifer were transferred. P1.2-1 and P1.3-6 developed 11 and 12 root nodules with $M$. polymorpha respectively, while $\mathrm{Pl} .4-2$ categorized into E. medicae developed 33 root nodules with the same host plant as shown in Fig. 6-A. This result shows that the root nodule forming ability of the symbiotic Agrobacterium is significantly lower than that of the $E$. medicae isolate. Similarly, regarding ethylene production by acetylene reduction assays, those of the two Agrobacterium isolates were clearly lower than that of $E$. medicae isolates shown in Fig. 6-B. Regarding St.3-13, the nodA sequence of this isolate was closely related to that of $E$. meliloti. The root nodule number of $M$. sativa inoculated with this isolate is clearly lower than that of host plants inoculated with the remaining isolates. Sullivan and Ronson (33) reported that a symbiotic element of Mesorhizobium loti was transferred into three non symbiotic species. Bailly et al. (2) reported that several interspecific horizontal gene transfers occurred during the diversification of Medicago symbionts. Similarly, Wong and Golding (41) reported that a large portion of pSym B genes in E. meliloti are most closely related to genes in Agrobacterium tumefaciens linear chromosomes. These reports support the existence of symbiotic Agrobacterium isolates produced by horizontal transfer of symbiotic genes. In this context, Velazquez et al. (39) reported for the first time the occurrence of two strains, named $163 \mathrm{C}$ and ATCC $11325^{\mathrm{T}}$, belonging to $R$. rhizogenes able to nodulate Phaseolus vulgaris. The two strains displayed symbiotic plasmids carrying nod and nif phylogenetically related to those of E. meliloti. Interestingly, Cumming et al. (7) characterized one bacterial strain IRBG 74 isolated from root nodules of Sesbania cannabina with a $16 \mathrm{~S}$ rRNA sequence closely related to that of
A. tumefaciens. This strain contained also a symbiotic plasmid carrying nodA and nifH similar to those in other Sesbania symbionts and this strain effectively nodulated Sesbania cannabina and even some others Sesbania species.

Moreover in this study, one isolate from M. polymorpha (P1.3-9) showed a $16 \mathrm{~S}$ rRNA sequence closely related to that of $E$. meliloti however its nodA sequence was similar to that of $E$. medicae. For this isolate, the sequencing of $16 \mathrm{~S}$ rRNA and nodA genes was repeated several times and the results were the same. This finding suggests gene transfer but further characterization of this isolate is needed to confirm its taxonomic status. Out of 4 isolates obtained from M. polymorpha, symbiotic genes of 3 isolates, Pl.2-1, Pl.3-6 and P1.3-9, seemed to undergo horizontal transfer from other species; however we have no clear answer to understand such a phenomenon.

\section{Nitrogen-fixing abilities of isolates having high abiotic stress tolerance}

According to Fig. 6-b, St. 1-3 and St.3-1 having high temperature resistance at $45^{\circ} \mathrm{C}$ and/or high salt resistance at $3 \% \mathrm{NaCl}$ showed relatively high nitrogen-fixing ability. These isolates were obtained from root nodules of $M$. sativa; therefore this demonstrated that $M$. sativa may be a convenient trap host to obtain candidate inoculants having both high abiotic stress tolerance and high nitrogen-fixing abilities. On the other hand, the most stress tolerant isolates from the four Medicago species showed promise as inoculants with the exception of Pl. 3-9 from M. polymorpha which showed a restricted spectrum of nitrogen fixation with Medicago species (Table 3). Furthermore, these stress tolerant isolates have been assigned to $E$. meliloti according to the $16 \mathrm{~S}$ rRNA gene sequencing. This finding suggests the application of these isolates as effective inoculants to Medicago species.

However, to obtain effective inoculants for Medicago species in arid and semi-arid climatic regions of Tunisia, we need further studies such as developing efficient screening methods for isolates using Medicago plants as trap hosts.

\section{Acknowledgements}

The authors are grateful to Tarek Slatni, Saber Kouas, Kais Zribi and Mounawer Badri (Biotechnology Center, Borj Cedria Techno-park, Tunisia) for kindly providing seeds and soil samples. Salem Djedidi is supported by a grant from the Tunisian Ministry of Higher Education, Scientific Research and Technology.

\section{References}

1. Badri, Y., K. Zribi, M. Badri, P. van-Berkum, and M.E. Aouani. 2007. Comparison of rhizobia that nodulate Medicago laciniata and Medicago truncatula present in a single Tunisian arid soil. Can. J. Microbiol. 53:277-283.

2. Bailly, X., I. Olivieri, B. Brunel, J.C. Cleyet-Marel, and G. Bena 2007. Horizontal gene transfer and homologous recombination drive the evolution of the nitrogen-fixing symbionts of Medicago species. J. Bacteriol. 189:5223-5236.

3. Bailly, X., I. Olivieri, S. De Mita, J.C. Cleyet-Marel, and G. Béna. 2006. Recombination and selection shape the molecular diversity pattern of nitrogen-fixing Sinorhizobium sp. associated to Medicago. Mol. Ecol. 15:2719-2734. 
4. Bena, G., A. Lyet, T. Huguet, and I. Olivieri. 2005. MedicagoSinorhizobium symbiotic specificity evolution and the geographic expansion of Medicago. J. Evolution. Biol. 18:1547-1558.

5. Broughton, W.J., and M.J. Dilworth. 1970. Methods in legumerhizobium technology: Plant nutrient solutions. p. 245-249. In P. Somasegaran, and H.J. Hoben (ed.), Handbook for Rhizobia. NifTAL Project and University of Hawaii, USA.

6. Cruz, F., and J. Davies. 2000. Horizontal gene transfer and the origin of species: Lessons from bacteria. Trends Microbiol. 8:128-133.

7. Cummings, S.P., P. Gyaneshwar, P. Vinuesa, et al. 2009. Nodulation of Sesbania species by Rhizobium (Agrobacterium) strain IRBG74 and other rhizobia. Environ. Microbiol.11:2510-2525.

8. Fall, D., D. Diouf, M. Ourarhi, A. Faye, H. Abdelmounen, M. Neyra, S.N. Sylla, and M.M. El Idrissi. 2008. Phenotypic and genotypic characteristics of Acacia senegal (L.) Wild. root-nodulating bacteria isolated from soils in the dryland part of Senegal. Lett. Appl. Microbiol. 47:85-97.

9. Galibert, F., T.M. Finan, S.R. Long, et al. 2001. The composite genome of the legume symbiont Sinorhizobium meliloti. Science 293:668-672.

10. Garau, G., W.G. Reeve, L. Brau, P. Deiana, R.J. Yates, D. James, R. Tiwari, G.W. O'Hara, and J.G. Howieson. 2005. The symbiotic requirements of different Medicago spp. suggest the evolution of Sinorhizobium meliloti and S. medicae with hosts differentially adapted to soil $\mathrm{pH}$. Plant Soil 276:263-277.

11. Ge-Hong, W., Y. Xue-Ying, Z. Zhi-Xin, Y. Ya-Zhen, and K. Lindsrom. 2008. Strain Mesorhizobium sp. CCNWGX035: A stresstolerant isolate from Glycyrrhiza glabra displaying a wide host range of nodulation. Pedosphere 18:102-112.

12. Hardy, R.W.F., R.D. Holsten, E.K. Jackson, and R.C. Burns. 1968 The acetylene-ethylene assay for $\mathrm{N}_{2}$ fixation: Laboratory and field evaluation. Plant Physiol. 43:1185-1207.

13. Hou, B.C., E.T. Wang, Y. Li, R.Z. Jia, W.F. Chen, C.X. Man, X.H Sui, and W.X. Chen. 2009. Rhizobial resource associated with epidemic legumes in Tibet. Microb. Ecol. 57:69-81.

14. Hung, M.H., A.A. Bhagwath, F.T. Shen, R.P. Devasya, and C.C. Young. 2005. Indigenous rhizobia associated with native shrubby legumes in Taiwan. Pedobiologia 49:577-584.

15. Irwin, J.A.G., D.L. Lloyd, and K.F. Lowe. 2001. Lucerne biology and improvement-an analysis of past activities and future goals in Australia. Aust. J. Agric. Res. 52:699-712.

16. Jebara, M., R. Mhamdi, M.E. Aouani, R. Ghrir, and M. Mars. 2001. Genetic diversity of Sinorhizobium populations recovered from different Medicago varieties cultivated in Tunisian soils. Can. J. Microbiol. 47:139-147.

17. Jordan, D.C. 1984. Family III. Rhizobiaceae Conn 1938. p. 234-244 In N.R. Krieg, and J.G. Holt (ed.), Bergey's Manual of Systematic Bacteriology, vol. 1. The Williams \& Wilkins Co., Baltimore, USA.

18. Kwon, S.W., J.W. Park, J.S. Kim, J.W. Kang, Y.H. Cho, C.K. Lim, M.A. Parker, and G.B. Lee. 2005. Phylogenetic analysis of the genera Bradyrhizobium, Mesorhizobium, Rhizobium and Sinorhizobium on the basis of 16S rRNA gene and internally transcribed spacer region sequences. Int. J. Syst. Evol. Microbiol. 55:263-270.

19. Liu, J., E.T. Wang, D. W. Ren, and W. X. Chen. 2010. Mixture of endophytic Agrobacterium and Sinorhizobium meliloti strains could induce nonspecific nodulation on some woody legumes. Arch Microbiol. 192:229-234.

20. Martens, M., M. Delaere, R. Coopman, P. De Vos, M. Gillis, and A. Willems. 2007. Multilocus sequence analysis of Ensifer and related taxa. Int. J. Syst. Evol. Microbiol. 57:489-503.

21. Merabet, C., M. Martens, M. Mahdhi, et al. 2010. Multilocus sequence analysis of root nodule isolates from Lotus arabicus (Senegal), Lotus creticus, Argyrolobium uniflorumand and Medicago sativa (Tunisia) and description of Ensifer numidicus sp. nov. and Ensifer garamanticus sp. nov. Int. J. Syst. Evol. Microbiol. 60:664674.

22. Minamisawa, K., M. Itakura, M. Suzuki, K. Ichige, T. Isawa, K. Yuhashi, and H. Mitsui. 2002. Horizontal transfer genes in soils and microcosms from Bradyrhizobium japonicum to B. elkanii. Microbes Environ. 17:82-90.

23. Moschetti, G., A.L. Peluso, A. Protopapa, M. Anastasio, O. Pepe, and R. Defez. 2005. Use of nodulation pattern, stress tolerance, nodC amplification, RAPD-PCR and RFLP-16S rDNA analysis to discriminate genotypes of Rhizobium leguminosarum biovar viciae. Syst. Appl. Microbiol. 28:619-631.

24. Nick, G., P. de Lajudie, B.D. Eardly, S. Suomalainen, L. Paulin, X Zhang, M. Gillis, and K. Lindstrom. 1999. Sinorhizobium arboris sp. nov. and Sinorhizobium kostiense sp. nov., isolated from leguminous trees in Sudan and Kenya. Int. J. Syst. Evol. Microbiol. 49:13591368 .
25. Payakapong, W., P. Tittabutr, N. Teaumroong, N. Boonkerd, P.W Singleton, and D. Borthakur. 2006. Identification of two clusters of genes involved in salt tolerance in Sinorhizobium sp. strain BL3. Symbiosis 41:47-51.

26. Portier, P., M.F. Le Saux, C. Mougel, C. Lerondelle, D. Chapulliot, J. Thioulouse, and X. Nesme. 2006. Identification of genomic species in Agrobacterium biovar 1 by AFLP genomic markers. Appl. Environ. Microbiol. 72:7123-7131.

27. Rome, S., M.A. Fernandez, B. Brunel, P. Normand, and J.C Cleyet-Marel. 1996. Sinorhizobium medicae sp. nov., isolated from annual Medicago spp. Int. J. Syst. Bacteriol. 46:972-980.

28. Saitou, N., and M. Nei. 1987. The neighbor-joining method: A new method for reconstructing phylogenetic trees. Mol. Biol. Evol. 4:406425 .

29. Sebbane, N., M. Sahnoune, F. Zakhia, A. Willems, S. Benallaoua, and P. de Lajudie. 2006. Phenotypical and genotypical characteristics of root-nodulating bacteria isolated from annual Medicago ssp. In Soummam Valley (Algeria). Lett. Appl. Microbiol. 42:235-241.

30. Seklani, H., and H. Hassen. 1990. Contribution a l'etude des especes spontanees du genre Medicago en Tunisie. Annales INRAT 63:3-15.

31. Shamseldin, A., J. Nyalwidhe, and D. Werner. 2006. A proteomic approach towards the analysis of salt tolerance in Rhizobium etli and Sinorhizobium meliloti strains. Curr. Microbiol. 52:333-339.

32. Shamseldin, A., M. El-Saadani, M.J. Sadowsky, and C.S. An 2009. Rapid identification and discrimination among Egyptian genotypes of Rhizobium leguminosarum bv. viciae and Sinorhizobium meliloti nodulating faba bean (Vicia faba L.) by analysis of nodC, ARDRA, and rDNA sequence analysis. Soil Biol. Biochem. 41:45-53.

33. Sullivan, G.T., and C.W. Ronson. 1998. Evolution of rhizobia by acquisition of a $500-\mathrm{kb}$ symbiosis island that integrates into a phe-tRNA gene. Proc. Natl. Acad. Sci. USA 95:5145-5149.

34. Suominen, L., C. Roos, G. Lortet, L. Paulin, and K. Lindstrom. 2001. Identification and Structure of the Rhizobium galegae common nodulation genes: Evidence for horizontal gene transfer. Mol. Biol. Evol. 18:907-916.

35. Tamura, K., J. Dudley, M. Nei, and S. Kumar. 2007. MEGA4: Molecular evolutionary genetics analysis (MEGA) software version 4.0. Mol. Biol. Evol. 24:1596-1599.

36. Thompson, J.D., T.J. Gibson, F. Plewniak, F. Jeanmougin, and D.G. Higgins. 1997. The CLUSTAL X windows interface: Flexible strategies for multiple sequence alignment aided by quality analysis tools. Nucleic Acids Res. 25:4876-4882.

37. Van Berkum, P., D. Beyene, G. Bao, T.A. Campbell, and B.D. Eardly. 1998. Rhizobium mongolense sp. nov. is one of the three rhizobial genotypes identified which nodulate and form nitrogen fixing symbiosis with Medicago ruthenica [(L.) Ledebour]. Int. J. Syst. Bacteriol. 48:13-22.

38. Van Berkum, P., P. Elia, and B.D. Eardly. 2006. Multilocus sequence typing as an approach for population analysis of Medicagonodulating rhizobia. J. Bacteriol. 188:5570-5577.

39. Velazquez, E., A. Peix, J.L. Zurdo-Pineiro, et al. 2005. The Coexistence of symbiosis and pathogenicity-determining genes in Rhizobium rhizogenes strains enables them to induce nodules and tumors or hairy roots in plants. Mol. Plant Microbe In. 18:1325-1332.

40. Vincent, J.M. 1970. A Manual for Practical Study of Root-Nodule Bacteria, IBP handbook 15. Blackwell Scientific Publications, Oxford.

41. Wong, K., and G.B. Golding. 2003. A phylogenetic analysis of the pSymB replicon from the Sinorhizobium meliloti genome reveals a complex evolutionary history. Can. J. Microbiol. 49:269-280.

42. Yokoyama, T., S. Ando, T. Murakami, and H. Imai. 1996. Genetic variability of the common nod gene in soybean bradyrhizobia isolated in Thailand and Japan. Can. J. Microbiol. 42:1209-1218.

43. Zakhia, F., H. Jedder, O. Domergue, A. Willems, J.C. Cleyet-Marel, M. Gillis, B. Dreyfus, and P. de Lajudie. 2004. Characterisation of wild legume nodulating bacteria (LNB) in the infra-arid zone of Tunisia. Syst. Appl. Microbiol. 27:380-395.

44. Zribi, K., R. Mhamdi, T. Huguet, and M.E. Aouani. 2005. Diversity of Sinorhizobium meliloti and S. medicae nodulating Medicago truncatula according to host and soil origins. World J. Microb. Biot. 21:1009-1015.

45. Zribi, K., R. Mhamdi, T. Huguet, and M.E. Aouani. 2004. Distribution and genetic diversity of rhizobia nodulating natural populations of Medicago truncatula in Tunisian soils. Soil Biol. Biochem. 6:903908.

46. Zribi, K., Y. Badri, S. Saidi, P. van Berkum, and M.E. Aouani. 2007. Medicago ciliaris growing in Tunisian soils is preferentially nodulated by Sinorhizobium medicae. Aust. J. Soil Res. 45:473-477. 